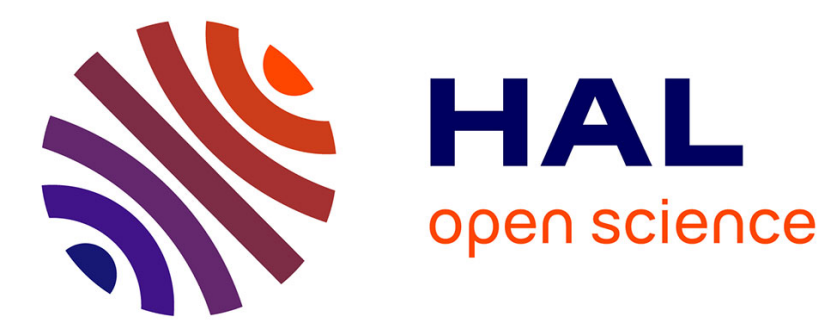

\title{
NMR assignments of the GacS histidine-kinase periplasmic detection domain from Pseudomonas aeruginosa PAO1
}

Ahmad Ali-Ahmad, Olivier Bornet, Firas Fadel, Yves Bourne, Florence

Vincent, Christophe Bordi, Françoise Guerlesquin, Corinne Sebban-Kreuzer

\section{To cite this version:}

Ahmad Ali-Ahmad, Olivier Bornet, Firas Fadel, Yves Bourne, Florence Vincent, et al.. NMR assignments of the GacS histidine-kinase periplasmic detection domain from Pseudomonas aeruginosa PAO1. Biomolecular NMR Assignments, 2017, 11 (1), pp.25-28. 10.1007/s12104-016-9714-7 . hal-01770251

\section{HAL Id: hal-01770251 \\ https://hal-amu.archives-ouvertes.fr/hal-01770251}

Submitted on 27 Aug 2018

HAL is a multi-disciplinary open access archive for the deposit and dissemination of scientific research documents, whether they are published or not. The documents may come from teaching and research institutions in France or abroad, or from public or private research centers.
L'archive ouverte pluridisciplinaire HAL, est destinée au dépôt et à la diffusion de documents scientifiques de niveau recherche, publiés ou non, émanant des établissements d'enseignement et de recherche français ou étrangers, des laboratoires publics ou privés. 


\section{NMR assignments of the GacS histidine-kinase periplasmic detection domain from Pseudomonas aeruginosa PAO1}

\author{
Ahmad Ali-Ahmad ${ }^{1} \cdot$ Olivier Bornet $^{2} \cdot$ Firas Fadel $^{1,2}$. \\ Yves Bourne $^{1}$ - Florence Vincent ${ }^{1}$ - Christophe Bordi ${ }^{2}$. \\ Françoise Guerlesquin ${ }^{2} \cdot$ Corinne Sebban-Kreuzer $^{2}$
}

\begin{abstract}
Pseudomonas aeruginosa is a highly adaptable opportunistic pathogen. It can infect vulnerable patients such as those with cystic fibrosis or hospitalized in intensive care units where it is responsible for both acute and chronic infection. The switch between these infections is controlled by a complex regulatory system involving the central GacS/GacA two-component system that activates the production of two small non-coding RNAs. GacS is a histidine kinase harboring one periplasmic detection domain, two inner-membrane helices and three H1/D1/H2 cytoplasmic domains. By detecting a yet unknown signal, the GacS histidine-kinase periplasmic detection domain ( $\mathrm{GacSp}$ ) is predicted to play a key role in activating the GacS/GacA pathway. Here, we present the chemical shift assignment of $96 \%$ of backbone atoms (HN, N, C, C $\alpha, \mathrm{C} \beta$ and $\mathrm{H} \alpha), 88 \%$ aliphatic hydrogen atoms and $90 \%$ of aliphatic carbon atoms of this domain. The NMR-chemical shift data, on the basis of Talos server secondary structure predictions, reveal that GacSp consists of $3 \beta$-strands, $3 \alpha$ helices and a major loop devoid of secondary structures.
\end{abstract}

Keywords Pseudomonas - Two-component system · GacS $\cdot$ Protein $\cdot$ NMR

Corinne Sebban-Kreuzer

corinne.kreuzer@imm.cnrs.fr

AFMB, CNRS, Aix Marseille Univ, Marseille, France

2 LISM, IMM, CNRS, Aix-Marseille Univ, 13402 Marseille, France

\section{Biological context}

Pseudomonas aeruginosa (PA) is a major opportunistic pathogen, responsible for nosocomial infections in immunocompromised patients. It can be involved in both acute and chronic infections (Gooderham and Hancock 2009). During acute infection, PA activates genes responsible for bacterial motility and excessive production of toxins that will be liberated in the extracellular medium or directly injected in host cells via type III secretion system. In contrast, chronic infections are characterized by formation of persistent bacterial communities enclosed by polysaccharide-rich matrix (biofilm) that provides high level of resistance against host innate immune response and antibacterial treatments (Furukawa et al. 2006). The switch between chronic and acute infection is regulated by a complex regulatory network involving two-component systems (TCSs), di-GMPc level and quorum sensing (QS). In this regard, environmental stresses and unknown signals detected by PA trigger expression of genes responsible for one infection type or another (Rasamiravaka et al. 2015).

TCSs are ubiquitous regulatory systems found in both prokaryotes and eukaryotes but absent from mammalians. They play essential role for the adaptation and survival of the organism by modulating cellular functions in response to environmental changes. TCSs comprise classically a membrane embedded histidine kinase (HK) sensor, which acts as a dimer, and a cognate response regulator (RR). Detection of environmental stimuli by the HK sensor leads to the autophosphorylation of its histidine kinase domains. The phosphate group is afterward transmitted to the cognate RR. Consequently, the activated RR triggers expression of different target genes (Mitrophanov and Groisman 2008). Comparing to $30 \mathrm{HKs}$ and $34 \mathrm{RRs}$ encoded by 
Escherichia. coli, PA uses $10 \%$ of its genes to encode for $64 \mathrm{HK}$ and $72 \mathrm{RR}$, which reflects the adaptation capacities of this bacterium (Rodrigue et al. 2000).

In PA, the GacS/GacA TCS plays a key role in the transition between acute and chronic infection that is antagonistically modulated by the two other hybrid histidine kinase sensors, LadS and RetS (Goodman et al. 2004; Ventre et al. 2006). The activation of GacS/GacA pathway induces expression of non-coding small RNA (sRNAs), RsmY and RsmZ (Brencic et al. 2009). Subsequently, an increased level of intracellular sRNAs leads to sequestrate the RNA-binding protein, RsmA. RsmA is a translational repressor that binds to mRNAs and modulates expression of more than 500 genes, including QS and T6SS gene. The GacS/GacA TCS positively regulates expression of genes required for biofilm formation, like psl and pel operons responsible for the production of Psl and Pel expolysaccharides that represent major components of the biofilm matrix. Conversely, it down-regulates expression of T3SS and motility factors (flagellum) (Bordi et al. 2010; Goodman et al. 2004).

$\mathrm{GacS}$ is a histidine kinase harboring one periplasmic detection domain, two inner-membrane helices and three H1/D1/H2 cytoplasmic domains. Compared to a classical $\mathrm{HK}$, the GacS HK is an unorthodox sensor that possesses a second receiver domain (D1) and an alternative histidinephosphotransfer domain (H2). In this case, the phosphorelay mechanism requires a four-step pathway. Autophosphorylation of a conserved His residue on the H1 domain initiates a series of phosphotransfer reactions involving HisH1 $\rightarrow$ AspD1 $\rightarrow$ HisH2. Afterward, the cognate response regulator GacA is activated by receiving a phosphate group from the GacS H2 domain (Chambonnier et al. 2016) In this system, GacSp is predicted to play a decisive sensing role. Whereas, post-binding conformational changes might engender structural rearrangements in the transmembrane helices leading to the activation of the $\mathrm{H} 1$ domain phosphorylation (Heeb and Haas 2001). Moreover, the nature of the signal that binds to GacSp is still unknown. To date, there is no structural information for this domain which limits our understanding regarding its mode of action. Here we report the backbone and side-chain resonance chemical shift assignments $\left({ }^{1} \mathrm{H},{ }^{13} \mathrm{C},{ }^{15} \mathrm{~N}\right)$ and identify the secondary structure elements of the periplasmic detection domain of the GacS HK sensor from PA.

\section{Expression and purification of GacSp}

The DNA sequence, coding for the periplasmic domain of GacS (38-164), was cloned into pET21a plasmid containing an oligohistidine tag (MGHHHHHHSSGVDLGTENLYFQS). E. coli BL21 (DE3) cells (Novagen) harboring
pET21a-gacSp were cultured overnight at $37^{\circ} \mathrm{C}$ in $100 \mathrm{~mL}$ of LB medium containing $50 \mu \mathrm{g} / \mathrm{mL}$ kanamycin and $34 \mu \mathrm{g} /$ $\mathrm{mL}$ chloramphenicol. The cells were harvested by centrifugation and resuspended in $1 \mathrm{~L}$ of $\mathrm{M} 9$ growth medium containing $4 \mathrm{~g} / \mathrm{L} \quad\left({ }^{13} \mathrm{C}\right)$-D-glucose, $1 \mathrm{~g} / \mathrm{L} \quad\left({ }^{15} \mathrm{~N}\right)-\mathrm{NH}_{4} \mathrm{Cl}$ (Cambridge isotope Laboratories), $50 \mu \mathrm{g} / \mathrm{mL}$ kanamycin and $34 \mu \mathrm{g} / \mathrm{mL}$ chloramphenicol. The culture was grown at $37{ }^{\circ} \mathrm{C}$ to an $\mathrm{OD}_{600}$ of 0.6 . IPTG $(0.2 \mathrm{mM})$ was added and the cells were incubated overnight at $20{ }^{\circ} \mathrm{C}$ for $\mathrm{GacSp}$ overproduction. Cells were harvested by centrifugation $\left(5000 \mathrm{~g}, 15 \mathrm{~min}, 10^{\circ} \mathrm{C}\right.$ ) and the pellet was resuspended in $50 \mathrm{~mL}$ of lysis buffer $(50 \mathrm{mM}$ Tris/ $\mathrm{HCl}, 300 \mathrm{mM} \mathrm{NaCl}$, $10 \mathrm{mM}$ imidazole, $5 \%$ glycerol, 1 tablet of SIGMAFAST $^{\mathrm{TM}}$ EDTA-free protease inhibitor cocktail and lysosyme $\mathrm{pH} 8$ ) and disrupted by sonication on ice after the addition of $20 \mathrm{mM} \mathrm{MgSO}_{4}$ and DNase. The lysate was clarified by centrifugation $\left(13,000 \times g, 40 \mathrm{~min}, 4^{\circ} \mathrm{C}\right)$ and the supernatant was applied onto nickel-chelate affinity resin column $(5 \mathrm{~mL})$ using an ÄktaXpress (GE-Healthcare). The column was washed with five volumes of $50 \mathrm{mM}$ Tris- $\mathrm{HCl}, 300 \mathrm{mM} \mathrm{NaCl}$, and $40 \mathrm{mM}$ imidazole $\mathrm{pH} 8$ and the protein was eluted with $50 \mathrm{mM}$ Tris- $\mathrm{HCl}$, $300 \mathrm{mM} \mathrm{NaCl}$, and $250 \mathrm{mM}$ imidazole $\mathrm{pH}$ 8. GacSp was concentrated and further purified by gel filtration (GF) on a Superdex75 16/60 column (GE-Healthcare) equilibrated with $50 \mathrm{mM}$ sodium phosaphate $\mathrm{pH} 7$ and $150 \mathrm{mM} \mathrm{NaCl}$ (GF buffer). Pure fractions of GacSp, as analyzed by SDSPAGE electrophoresis, were pooled and concentrated to $12.5 \mathrm{mg} / \mathrm{mL}$ using a $10 \mathrm{kDa}$ cut-off ultracentrifugation membrane (Thermoscientific).

\section{NMR spectroscopy}

NMR data were collected at $298 \mathrm{~K}$ on a $0.8 \mathrm{mM}$ sample of ${ }^{13} \mathrm{C},{ }^{15} \mathrm{~N}$-labeled GacSp in GF buffer containing $10 \% \mathrm{D}_{2} \mathrm{O}$. All the NMR experiments required for backbone and sidechain assignment were recorded on Bruker Avance III $600 \mathrm{MHz}$ spectrometer (IMM NMR platform, Marseille) and on a $950 \mathrm{MHz}$ Bruker Avance III HD spectrometer (IR-RMN, Grenoble), respectively. Both spectrometers were equipped with a TCI cryoprobe. Data were processed using Topspin 2.1 (Brucker) and analysed by using the program CARA (keller 2004). Backbone chemical shifts were assigned using $\mathrm{HNCA}, \mathrm{HN}(\mathrm{CO}) \mathrm{CA}, \mathrm{CBCANH}$, $\mathrm{CBCA}(\mathrm{CO}) \mathrm{NH}, \mathrm{HNCO}$ and $\mathrm{HN}(\mathrm{CA}) \mathrm{CO}$. These values were used to calculate backbone torsion angles $(\Phi$ and $\psi)$ using TALOS + server (Shen et al. 2009). Aliphatic side chain carbons were identified using HNHA, HCCHTOCSY, 2D HSQC-TOCSY, ${ }^{15} \mathrm{~N}-\mathrm{HSQC}-\mathrm{TOCSY},{ }^{15} \mathrm{~N}-$ HSQC-NOESY. Aromatic side chain resonances were assigned using the 2D HSQC-NOESY and the three-dimensional ${ }^{13} \mathrm{C}$-HSQC-NOESY spectra. 


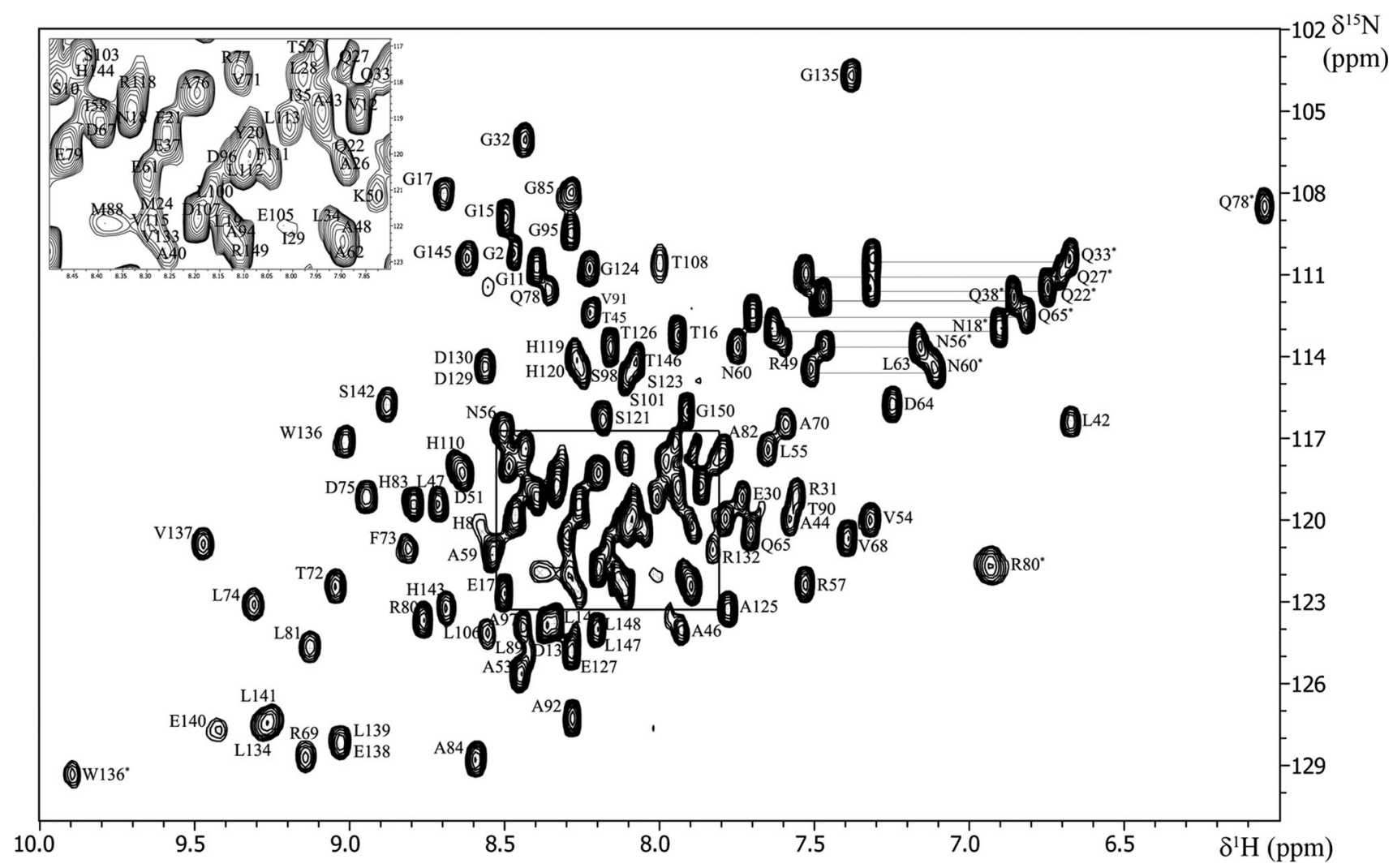

Fig. $1{ }^{1} \mathrm{H},{ }^{15} \mathrm{~N}$-HSQC spectrum of GacSp in $150 \mathrm{mM} \mathrm{NaCl}, 50 \mathrm{mM}$ $\mathrm{KPO}_{4}$ buffer $\mathrm{pH} 7,10 \% \mathrm{D}_{2} \mathrm{O}$, at $298 \mathrm{~K}$ on a Bruker Avance III $600 \mathrm{MHz}$ spectrometer. The backbone ${ }^{1} \mathrm{H},{ }^{15} \mathrm{~N}$ correlations are labeled

according to the sequence. Side chain amine resonances are indicated with star. Side chain resonances of Gln and Asn residues are connected by horizontal lines

\begin{tabular}{|c|c|c|c|c|c|c|c|}
\hline 10 & 20 & & 40 & $\alpha 2$ & $\alpha 3^{6}$ & & ${ }^{0} \beta 1$ \\
\hline & & & & & & & \\
\hline & & HHHHHHHH & & & $\mathrm{HHHHHHHH}$ & LLLEE & \\
\hline 8000 & 8876886043 & 5837999999 & 9999950005 & 6889999638 & 6899999999 & 9952899669 & 99998 \\
\hline
\end{tabular}

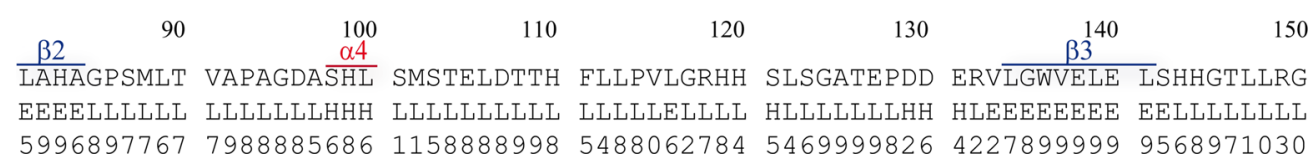

Fig. 2 GacSp secondary structure predictions and the confidence scores $(0-10)$ as derived from a Talos + analysis $(\mathrm{H}$ for $\alpha$-helix, E for $\beta$-strand an $\mathrm{L}$ for loop)

\section{Assignments and data deposition}

The ${ }^{1} \mathrm{H},{ }^{15} \mathrm{~N}$ HSQC spectrum of GacSp, recorded at $298 \mathrm{~K}$, contains 153 resonances of which 18 correspond to amine groups of glutamine and asparagine and seven correspond to $\mathrm{NH} \varepsilon$ group of arginine side chains (Fig. 1). The first nine residues of the His-tag, except $\mathrm{G} 2$ and $\mathrm{H} 8$, and $\mathrm{S} 23$, R25, S87, H99 and L116 were not assigned. In total, greater than $96 \%$ of backbone atoms ( $\mathrm{HN}, \mathrm{N}, \mathrm{C}, \mathrm{C} \alpha, \mathrm{C} \beta$ and $\mathrm{H} \alpha), 88 \%$ aliphatic hydrogen atoms and $90 \%$ of aliphatic carbons atoms were assigned. Roughly $50 \%$ of the aromatic side chains atoms were attributed, probably due to unfavourable exchange dynamics and GacSp unstable conformation.

The results of the secondary structure prediction, carried out on TALOS + server, are shown in (Fig. 2). GacS is predicted to harbor three $\mathrm{N}$-terminal $\alpha$-helices $(\alpha 1, \alpha 2$ and $\alpha 3)$ followed by two $\beta$-strands $(\beta 1, \beta 2)$, one $\alpha$-helix $(\alpha 4)$ and a $\beta$-strand ( $\beta 3$ ). A major loop (32 residues) is predicted to link $\alpha 4$ and $\beta 3$. Chemical shift assignments for GacSp have been deposited in the BioMagResBank (http://www. bmrb.wisc.edu) under the accession number 26840 . 
Acknowledgments The authors thank Drs. A. Favier at the Institut de Biologie Structurale and the TGIR-RMN-THC FR3050 CNRS (Grenoble, France) for data collection.

\section{References}

Bordi C, Lamy MC, Ventre I, Termine E, Hachani A, Fillet S, Roche B, Bleves S, Méjean V, Lazdunski A, Filloux A (2010) Regulatory RNAs and the HptB/RetS signalling pathways finetune Pseudomonas aeruginosa pathogenesis. Mol Microbiol 76:1427-1443

Brencic A, McFarland KA, McManus HR, Castang S, Mogno I, Dove SL, Lory S (2009) The GacS/GacA signal transduction system of Pseudomonas aeruginosa acts exclusively through its control over the transcription of the RsmY and RsmZ regulatory small RNAs. Mol Microbiol 73:434-445

Chambonnier G, Roux L, Redelberger D, Fadel F, Filloux A, Sivaneson M, de Bentzmann S, Bordi C (2016) The hybrid histidine kinase LadS forms a multicomponent signal transduction system with the $\mathrm{GacS} / \mathrm{GacA}$ two-component system in pseudomonas aeruginosa. PLoS Genet 12:e1006032

Furukawa S, Kuchma SL, O’Toole GA (2006) Keeping their options open: acute versus persistent infections. J Bacteriol 188:1211-1217

Gooderham WJ, Hancock RE (2009) Regulation of virulence and antibiotic resistance by two-component regulatory systems in Pseudomonas aeruginosa. FEMS Microbiol Rev 33:279-294
Goodman AL, Kulasekara B, Rietsch A, Boyd D, Smith RS, Lory S (2004) A signaling network reciprocally regulates genes associated with acute infection and chronic persistence in Pseudomonas aeruginosa. Dev Cell 7:745-754

Heeb S, Haas D (2001) Regulatory roles of the GacS/GacA twocomponent system in plant-associated and other gram-negative bacteria. Mol Plant Microbe Interact 14:1351-1363

Keller R (2004) The computer aided resonance assignment tutorial. CANTINA Verlag, Goldau, pp 1-81

Mitrophanov AY, Groisman EA (2008) Signal integration in bacterial two-component regulatory systems. Genes Dev 22:2601-2611

Rasamiravaka T, Labtani Q, Duez P, El Jaziri M (2015) The formation of biofilms by Pseudomonas aeruginosa: a review of the natural and synthetic compounds interfering with control mechanisms. Biomed Res Int 2015:759348

Rodrigue A, Quentin Y, Lazdunski A, Méjean V, Foglino M (2000) Two-component systems in Pseudomonas aeruginosa: why so many? Trends Microbiol 8:498-504

Shen Y, Delaglio F, Cornilescu G, Bax A (2009) TALOS+: a hybrid method for predicting protein backbone torsion angles from NMR chemical shifts. J Biomol NMR 44:213-223

Ventre I, Goodman AL, Vallet-Gely I, Vasseur P, Soscia C, Molin S, Bleves S, Lazdunski A, Lory S, Filloux A (2006) Multiple sensors control reciprocal expression of Pseudomonas aeruginosa regulatory RNA and virulence genes. Proc Natl Acad Sci USA 103:171-176 